\author{
dr Beata Skubiak* \\ mgr Malgorzata Taraszkiewicz**
}

\title{
BADANIA NEURONAUK A ROZWIĄZYWANIE PROBLEMÓW SPOLECZNYCH
}

\author{
NEURODIDACTIC RESEARCH AND SOLUTION \\ OF SOCIAL PROBLEMS
}

\begin{abstract}
Social phenomena influence the development processes of the economy and for this reason the problem of marginalization and social exclusion is much more significant. In addition, the sense and deepening of the common good with a specific territory manifests itself in the involvement of its inhabitants in the implementation of various types of projects and programs. The involvement of local communities can be the basis for launching development processes which are based on endogenous factors.

In this context, the aim of the article is to show how the results of research in the area of neurosciences can contribute to coping with social problems on the example of problem regions, when solving failures repeatedly. This is exemplified by the activation of people who are excluded or at risk of social exclusion.
\end{abstract}

Keywords: social problems, problem areas, neuroscience

JEL classification: R19, O2, R1

* Uniwersytet Szczeciński, Wydział Nauk Ekonomicznych i Zarządzania; bskubiak@wneiz.pl

** Grupa edukacyjna 21; malgorzata.taraszkiewicz@wp.pl 


\section{Wprowadzenie}

Nowoczesne neuronauki oferują duże możliwości w zakresie badania związków między procesami biologicznymi a zachowaniami społecznymi. Powodem wzrostu zainteresowania neuronaukami jest coraz powszechniejsze wśród badaczy przekonanie, że wiele ważnych zjawisk społecznych wymaga interdyscyplinarnego podejścia, które pozwoli na ich wielopoziomową analizę ${ }^{1}$. Autorki artykułu uważają, że podejście biologiczne ma wiele do zaoferowania psychologom społecznym. Dobrze zinterpretowane badania z zastosowaniem metod neuronauk mogą przyczynić się do głębszego, multidyscyplinarnego rozumienia zjawisk społecznych, które z kolei wywierają wpływ na procesy rozwoju gospodarki i z tego punktu widzenia szczególnie istotny wydaje się problem marginalizacji² i wykluczenia społecznego ${ }^{3}$. Marginalizacja, której pośrednią przyczyną jest nierówność społeczna oraz stratyfikacja, powodowana jest wieloma czynnikami. Do tych ważnych należałoby zaliczyć: problemy z pracą, ubóstwo, biedę, alkoholizm, narkomanię, bezdomność, problem dysfunkcyjności i niepełnosprawności. Marginalizacja kojarzy się także z wygnaniem, odizolowaniem jednostki, wyłączeniem jej ze społeczeństwa i brakiem akceptacji w środowisku. Oznacza też brak możliwości korzystania z życia społecznego. Marginalizację dość często lokuje się obok wykluczenia społecznego albo w ogóle z nim utożsamia. Wykluczenie dotyczy osób, rodzin, grup ludności, które żyją w trudnych warunkach ekonomicznych (ubóstwo materialne), zostają dotknięte niekorzystnymi procesami społecznymi wynikającymi z masowych i dynamicznych zmian rozwojowych, np. z dezindustrializacji, kryzysów, gwałtownego upadku branż czy regionów. Osoby te nie zostały wyposażone w kapitał życiowy umożliwiający im osiągnięcie normalnej pozycji społecznej i odpowiedniego poziomu kwalifikacji, wejście na rynek pracy lub założenie rodziny, co dodatkowo utrudnia dostosowywanie się do zmieniających się warunków społecznych i ekonomicznych. Nie posiadają również dostępu do odpowiednich instytucji pozwalających na wyposażenie w kapitał życiowy, jego rozwój i pomnażanie - ze względu na niedorozwój tych instytucji spowodowany brakiem priorytetów i wystarczających środków publicznych, a także niską

1 J.T. Cacioppo, G.G. Berntson, Social psychological contributions to the decade of the brain: doctrine of multilevel analysis, „American Psychologist” 1992, Vol. 47, s. 1019-1028.

2 Proces społecznego wykluczania pewnych grup ludzi z uwagi na względnie trwałą niezgodność ich postępowania z przyjętym przez dane społeczeństwo zespołem norm społecznych (https://encyklopedia.pwn.pl/haslo/marginalizacja;3937739.html [dostęp: 21.06.2019]).

3 W dokumentach krajowych (Narodowa Strategia Integracji dla Polski, Ministerstwo Gospodarki, Pracy i Polityki Społecznej, Warszawa 2003, s. 21) i międzynarodowych określenia wykluczenia społecznego koncentrują się na ustalonych wymiarach zjawiska, np. ograniczeniach instytucjonalno-prawnych, dominującym ryzyku zagrożenia wykluczeniem, grupach osób dotkniętych wykluczeniem społecznym lub na ukazywaniu obszarów, do których nastąpiło ograniczenie dostępu (np. do konsumpcji, informacji czy też kultury). 
efektywnością funkcjonowania. Osoby te doświadczają dyskryminacji zarówno wskutek niedorozwoju właściwego ustawodawstwa, jak i kulturowych uprzedzeń oraz stereotypów, do tego mają cechy utrudniające im korzystanie z powszechnych zasobów społecznych z racji niesprawności, uzależnienia, długotrwałej choroby albo innych cech indywidualnych; padają ofiarą niszczącego działania ze strony innych osób, np. przemocy, szantażu, indoktrynacji.

Dodatkowo poczucie więzi z określonym terytorium i chęć pogłębiania wspólnego dobra przejawiają się w zaangażowaniu jego mieszkańców w realizację różnego typu projektów i programów. Zaangażowanie lokalnych wspólnot może stanowić podstawę uruchomienia procesów rozwojowych opartych na czynnikach endogennych. Społeczność lokalna posiada zdolność do reagowania na określone plany rozwoju lokalnego, potrafi zmobilizować posiadane zasoby, dostosować swoje organizacje do bieżących potrzeb i opracować własne, odpowiednie do sytuacji, strategie zarządzania. W zakresie zapewnienia dobrego zarządzania społeczności lokalne mają do odegrania kluczową rolę jako łącznik $\mathrm{w}$ administracji samorządowej.

Celem artykułu jest pokazanie, w jaki sposób wyniki badań z obszaru tzw. neuronauk mogą przyczynić się do lepszego radzenia sobie z problemami społecznymi regionów problemowych ${ }^{4}$, przy których rozwiązywaniu wielokrotnie ponosi się porażki. Jako przykład posłużyć może aktywizacja osób wykluczonych lub zagrożonych wykluczeniem społecznym.

\section{Problemy społeczne - studium obszarów problemowych ${ }^{5}$}

$\mathrm{Na}$ obszarach problemowych do grup społecznych, które z racji kształtowania się niekorzystnych czynników doświadczają marginalizacji, izolacji społecznej, zaliczyć można te dotknięte biedą, ubóstwem materialnym, a także alkoholizmem, narkomanią, przestępczością (szczególnie wśród nieletnich), bezrobociem wśród młodzieży, chorobami psychicznymi czy niepełnoprawnością. Ze względu na obszerność wymienionych zagadnień nie zostaną tu one szczegółowo omówione.

W regionach problemowych sytuacja w zakresie niekorzystnych zjawisk społecznych jest tym trudniejsza, że dominujące postawy ludzkie są zupełnie niezgodne

${ }^{4}$ Obszary problemowe stanowią specjalną podkategorię, wskazując, że jest to obszar strategicznej interwencji państwa, na którego terenie identyfikowane są zjawiska niekorzystne dla jego rozwoju społeczno-gospodarczego oraz ludności.

${ }^{5}$ Opracowano na podstawie lokalnych programów rewitalizacji gmin: Recz, Choszczno, Pyrzyce, które zaliczane są do obszarów problemowych. W województwie zachodniopomorskim obszary problemowe noszą nazwę tzw. Specjalnej Strefy Włączenia. 
ze standardami wyznaczanymi przez obie formy kapitału - fizyczny i ludzki ${ }^{6}$. Są to raczej postawy sprzyjające tworzeniu się zasobów antykapitału społecznego. W tych warunkach znaczenia nabierają działania wspierające powstawanie różnych instytucji, w szerokim tego słowa znaczeniu odzwierciedlających działanie kapitału społecznego i kapitału ludzkiego. W wypadku regionów problemowych jednak kreacja tych elementów jest bardzo forsowna. Dominujące postawy w społecznościach zamieszkujących regiony problemowe nie sprzyjają tworzeniu kapitału ludzkiego i kapitału społecznego. Nie ma bowiem powszechnej skłonności do: edukacji, podwyższania swoich kwalifikacji i umiejętności czy rozwijania predyspozycji i osobistych talentów. Trudno o postawy twórcze, przedsiębiorcze czy innowacyjne poszukiwania. Wręcz przeciwnie, przeważają postawy charakteryzujące się: obojętnością, przyzwyczajeniem, pogodzeniem się z biedą i brakiem perspektyw. Edukacja jest traktowana jako niepożądany obowiązek lub forma organizowania wolnego czasu. Ludzie stawiają sobie i innym niskie wymagania i zadowalają się „bylejakością”. Jest ona powszechna, widoczna w zachowaniach, działaniach, a nawet w wyglądzie. Upowszechniają się patologie społeczne $\mathrm{w}$ formie: alkoholizmu, przestępczości czy przemocy i nie spotykają się one ze społeczną regulacją. Uważa się nawet, że należy je akceptować jako przejawy swoistej życiowej zaradności. Nieliczne społeczne inicjatywy są traktowane z nieufnością, częściej spotykają się z brakiem zainteresowania bądź skłonnością do zachowań syndromicznych czy wręcz kontestujących, takich jak protesty. Aktywność obywatelska lub partycypacja społeczna ogranicza się do oczekiwania na pomoc ze strony państwa i instytucji zewnętrznych wraz z upowszechnianiem postaw roszczeniowych. Brakuje w takich sytuacjach sieci elementów, które decydują o rozmiarach i jakości kapitału społecznego i kapitału ludzkiego. Bez tej struktury regiony problemowe nie będą w stanie wejść na jakąkolwiek drogę rozwoju cywilizacyjnego, nawet wykorzystując tradycyjne, ekstensywne czynniki

\section{Neuronauki a rozwiązywanie problemów społecznych}

W świetle neuronauk kluczowym pojęciem jest neuroplastyczność mózgu oraz dziedziczenie tzw. drugiego kodu, którym zajmuje się epigenetyka. Zacznijmy od neuroplastyczności. Marian Diamond należy do twórców nowoczesnej neurobiologii - badała zagadnienie neuroplastyczności i wzbogacania mózgu, a jej

${ }^{6}$ Kapitał ludzki potocznie rozumiany jest jako wiedza, umiejętności, zdolności, postawy, motywacja czy nawet stan zdrowia; jest to wiedza osadzona w relacjach i stosunkach społecznych, a wiąże się z zaufaniem członków organizacji do siebie, z normami i wartościami.

${ }^{7}$ Więcej na ten temat zob.: A. Becla, S. Czaja, Rola kapitału ludzkiego i społecznego w określaniu ścieżki rozwoju ekonomicznego w regionach problemowych, „Optimum. Studia Ekonomiczne” 2014, nr 2(68), s. 16-28; J. Bauer, Granica bólu. O źródtach agresji i przemocy, Dobra Literatura, Słupsk 2015. 
ustalenia podważały dotychczasową wiedzę na temat mózgu i genetyki, niezmienności potencjału mózgu. Najważniejszy wniosek z tych badań brzmi: mózg nie jest zdeterminowany przez genetykę, tylko ulega wpływom środowiska. Najważniejsze czynniki pozytywnego wpływu środowiska na rozwój mózgu to: odpowiednia dieta, ruch, pokonywanie trudności, nowość oraz troska i miłośćs. Szczególnie jest to ważne w krytycznych okresach rozwoju człowieka, kiedy formatują się przekonania na temat siebie i świata oraz własnego sprawstwa: co możemy, czego nie możemy, jak żyć?... W środowiskach dysfunkcyjnych dziecko otrzymuje pakiet negatywnych doświadczeń (o czym będzie mowa dalej), ale też w wyniku traumatycznych przeżyć dokonują się zmiany w mózgu. Te zmiany wywołuje nadaktywność hormonów adrenaliny i noradrenaliny. Ciągły stres powoduje nadaktywność tych hormonów, strukturalne zmiany w neuronach i zmiany w genach. Jeden z ważniejszych neuroprzekaźników - serotonina, moduluje wszystkie nasze emocje. Zbyt niski poziom serotoniny, a wysoki noradrenaliny wywołuje zachowania agresywne i przemocowe. Zbyt niski poziom noradrenaliny jest powodem zachowań ryzykownych, impulsywnych i pełnych afektu, alkoholizmu, a także depresji. Na poziom serotoniny i noradrenaliny mają wpływ m.in. alkoholizm lub narkomania rodziców oraz zażywanie sterydów. Agresywne zachowania są wywoływane ponadto zatruciem ołowiem, który narusza równowagę chemiczną organizmu. W rodzinach, w których obserwuje się wyższe wskaźniki przemocy, wykryto enzym monoaminooksydazy A - gen agresji. Ten enzym ujawnia się wyłącznie w męskiej populacji. Obecnie nauka potrafi częściowo zbilansować chemię mózgu, a zwłaszcza zwiększać poziom serotoniny. Traumatyczne przeżycia dziecka we wczesnym rozwoju mogą zatem wpłynąć na poziom serotoniny i noradrenaliny, a jego rozwój fizyczny i umysłowy zaburzają ponadto zażywane przez rodziców narkotyki i alkohol - i to kształtuje wczesną matrycę zachowań jednostki.

Kolejnymi czynnikami wpływającymi na rozwój umysłowy i fizyczny człowieka są niedożywienie i nieprawidłowa dieta oraz zatrucia (np. ołowiem i rtęcią). Niestety większość współczesnych dzieci jest przekarmiana i jednocześnie niedożywiona. Szczególnie niedożywiony jest mózg. Współczesna żywność, zwłaszcza ta najtańsza, ma bardzo niskie walory odżywcze. W eksperymentach prowadzonych przez autorkę niniejszego artykułu $\mathrm{z}$ dziećmi w wieku szkolnym, które cechowały się nadaktywnością, zachowaniami przemocowymi i kłopotami z uczeniem się, we współpracy z rodzicami zastosowano miesięczny plan „diety życiowej”, która polegała na: (1) odstawieniu na miesiąc żywności typu fast food, słodyczy, chipsów, napojów typu cola i innej żywności wysoko przetworzonej

${ }^{8}$ Film Dr Diamond - mózg moja miłość, https://www.youtube.com/watch?v=WR_cEutJNPo [dostęp: 21.06.2019].

${ }_{9}^{9}$ Małgorzata Taraszkiewicz, eksperyment przeprowadzony w warszawskich szkołach w klasach IV SP w latach 2011-2012. 
o niskiej wartości odżywczej; ponadto (2) poproszono rodziców o podawanie dzieciom wody do picia i (3) o 15-minutowe wspólne czytanie. Rodzice zostali odpowiednio poinstruowani, uczniowie zaś wzięli udział w 30 godzinnych warsztatach, których celem była rekonstrukcja ich niekorzystnych doświadczeń. Efekty były zdumiewająco dobre. Grupa uczniów z etykietą ,najgorsza klasa w szkole" po miesiącu oddziaływań została uznana za aktywną, spokojną i kompetentną - odmienioną na lepsze.

Podobne efekty zaobserwowano w dużej grupie uczniów (ok. 20 tysięcy dzieci), którzy brali udział w projektach „Umiem się uczyć” i „Potrafię. Wiem. Znam. Radę sobie dam" ${ }^{\prime 10}$ (w latach 2007-2013). Byli to uczniowie często z dużymi trudnościami w nauce i zachowaniu, tymczasem po 40 godzinach specjalnie zaprojektowanych doświadczeń zaszła oczekiwana przemiana niemal w 100\% przypadków. Zmiany dotyczyły uczniów, nauczycieli i rodziców. Zastosowano tutaj metodę transformacji przekonań i rekonstrukcję/uzupełnienie brakujących kompetencji nie tylko związanych z umiejętnościami uczenia się, ale także z zakresu zaufania do siebie, wiary w siebie, poczucia sprawstwa i poczucia własnej wartości.

Z badań wynika, że najsilniejszy wpływ na zmianę mają doświadczenia przełomowe, naruszające utrwalony obraz siebie i świata (np. zmiana z ,jestem słaby, nic nie umiem” na „wiem i umiem, jestem dobry, jestem OK.” lub z ,życie to dżungla, gdzie trzeba walczyć o przetrwanie” na „świat jest generalnie przyjazny, a ja umiem sobie poradzić z problemami”, albo ze „szkoła, nauczyciele - to nie dla mnie, do niczego się nie nadaję" na ,jestem ważny i kompetentny").

Doświadczenie lepszego siebie jest momentem przełomowym. Takie doświadczenia miały np. kobiety odbywające wyroki w więzieniu. $\mathrm{Z}$ pomocą arteterapii docierano $u$ nich do sthumionych emocji, postaw i budowano nowe perspektywy. Jednym ze sposobów oddziaływań był udział w warsztatach z wizażu. Kobietom - przy pomocy kosmetyczek, fryzjerów i stylistów - pokazano ich nowe wizerunki. Dla wielu z nich to był przełom, który zmienił ich życiowe decyzje i powiódł je ku lepszym perspektywom.

Bardzo ciekawy eksperyment przeprowadził M. Lipman ${ }^{11}$ w szkołach jednego z okręgów Nowego Jorku. Życie w tym okręgu upływa w atmosferze biedy, przemocy, aktywności gangów i ogólnej beznadziei. Lipman uczył uczniów myślenia w kategoriach przyczyn i skutków, logiki, badania przekonań itd., wykorzystując do tego filozofowanie. Zmiany były spektakularne!

10 Projekt POKL „Umiem się uczyć” i „Potrafię. Wiem. Znam. Radę sobie dam”, ewaluacja: http://kiw-pokl.org.pl/media/upload/951/Raport\%20z\%20ewaluacji\%20zewn\%C4\%99trznej.pdf3. Małgorzata Taraszkiewicz była autorką programu doskonalenia dla nauczycieli oraz scenariuszy warsztatów dla uczniów klas IV-VI SP. 2008.

${ }^{11}$ M. Lipman, Filozofia w szkole, Centralny Ośrodek Doskonalenia Nauczycieli, Warszawa 
Jak widać pomoc grupom defaworyzowanym w metodologii oddziaływań wynikających z neuronauk i epigenetyki polega na istotnej rekonstrukcji nabytych doświadczeń, zmianie przekonań i wyposażeniu w nowe kompetencje, które mają charakter włączający w pozytywny nurt wydarzeń. Wpływa to także na zmianę stylu życia. Tylko takie, głębokie oddziaływania umożliwiają wyrwanie się sensu stricto z pętli doświadczeń nabytych w dzieciństwie i w środowisku, w którym dane osoby dorastały lub żyły. Tylko takie oddziaływania wpływają na trwałe zmiany w mózgu, a co za tym idzie - na pojawienie się nowych funkcjonalnych formatów zachowań. Nikt nie chce być wykluczony ze świata, w którym żyje.

Pomoc społeczna w postaci talonów na bezpłatne obiady, ubrania czy comiesięczny zasiłek tylko utrwala zachowania bezradnościowe, tworząc dodatkowe uzależnienie od pomocy społecznej.

\section{Podsumowanie i wnioski}

„Wiele wskazuje na to, że dzieci urodzone w rodzinach z niskim statusem socjoekonomicznym wyciągnęły krótszą zapałkę"12. To niestety na ogół silnie wpływa na ich dalsze losy. Profesor Heckman, noblista z University of Chicago Economic, stwierdza: „Inwestowanie w dzieci z nieuprzywilejowanych rodzin jest rzadko spotykaną, znakomitą inicjatywą publiczną, promującą równe traktowanie i sprawiedliwość społeczną i jednocześnie wspierającą produktywność gospodarki i społeczeństwa w całości”'13. Ponadto najlepiej, gdy objęte są nią jednostki we wczesnym dzieciństwie: „Wzajemne oddziaływania genotypu i środowiska wpływają na architekturę mózgu i wykształcanie umiejętności. Co oznacza, że wzajemna gra genów i doświadczeń ma znaczenie dla rozwijającego się mózgu, który jest niebywale plastyczny i szczególnie wrażliwy na wpływy środowiskowe we wczesnym dzieciństwie. Po drugie, nabywanie umiejętności podlega zasadom hierarchiczności. Najpierw należy opanować umiejętności podstawowe, zanim można przejść do kolejnego poziomu. Po trzecie, umiejętności wzajemnie od siebie zależą i podlegają wpływom doświadczenia. I po czwarte, istnieją okresy zwiększonej wrażliwości, kiedy mózg jest najbardziej plastyczny"14. Cztery założenia Heckmana idealnie pasują do wyników badań prowadzonych w ramach

${ }^{12}$ K. Asbury, R. Plomin, Geny i edukacja, Wydawnictwo Naukowe PWN, Warszawa 2017.

13 J.J. Heckman, Investing in disadvantaged young children is an economically efficient pol$i c y$, presented at the Committee for Economic Development/The Pew Charitable Trusts/PNC Financial Services Group Forum on „Building the Economic Case for Investments in Preschool”, New York, January 10, 2016, https://www.youtube.com/watch?v=pq ubRXwEXc\&feature=youtube [dostęp: 21.06.2019].

${ }^{14}$ Ibidem. 
genetyki behawioralnej, wskazujących, że wpływy środowiska wspólnego mają największe znaczenie w okresie przedszkolnym.

Geny wyjaśniają przeciętnie około połowy różnic indywidualnych pod względem zdolności poznawczych. Za drugą połowę odpowiadają środowisko i wychowanie.

Choć status socjoekonomiczny jest predyktorem osiągnięć szkolnych i podlega wpływom genów, tworzenie interwencji uwzględniających oddziaływania środowiskowe, niwelujących skutki biedy, ograniczonej stymulacji, przeludnienia i chaosu, jest najlepszą drogą, jaką możemy obrać, jeżeli naszym celem rzeczywiście jest wyrównywanie szans. Żadnych problemów nie rozwiąże się, oddziałując na poziomie, na którym się manifestują.

Autorki artykułu uważają w związku z tym, że:

- dofinansowanie biedy tylko utrwala nieprawidłowe schematy zachowań i przekonań, a tym samym utrwala zjawisko, które ma być przepracowane i rozwiązane,

- instrumentami zmiany są odpowiednio sprofilowana edukacja i odpowiednio zaprojektowane programy edukacyjne - edukacja rewitalizacyjna,

- w tym celu genetyka edukacyjna powinna tworzyć podstawową część wszelkich programów kształcenia nauczycieli i osób zajmujących się pomocą i polityką społeczną, a także lekarzy i osób zajmujących się opieką okołoporodową,

- rozwiązywanie problemów społecznych za pomocą pomocy finansowej i materialnej jest myśleniem magicznym, utrwalającym charakterystyczne postawy, przekonania i wartości, które są przeciwrozwojowe,

- istnieje pilna potrzeba wykształcenia specjalistów w zakresie działań rewitalizacyjnych $\mathrm{w}$ obszarze edukacji i opracowania programów interwencyjnych (wykorzystujących wnioski z badań w obszarze neuronauk i epigenetyki), których celem jest wywołanie trwałej zmiany u osób/grup defaworyzowanych i wykluczonych społecznie,

- długofalowo okaże się to korzystne zarówno społecznie, jak i ekonomicznie dla jednostek oraz całego społeczeństwa.

\section{Bibliografia}

Asbury K., Plomin R., Geny i edukacja, Wydawnictwo Naukowe PWN, Warszawa 2017.

Bauer J., Granica bólu. O źródtach agresji i przemocy, Dobra Literatura, Słupsk 2015.

Becla A., Czaja S., Rola kapitału ludzkiego i społecznego w określaniu ścieżki rozwoju ekonomicznego w regionach problemowych, „Optimum. Studia Ekonomiczne” 2014, nr 2(68), s. 16-28.

Cacioppo J.T., Berntson G.G., Social psychological contributions to the decade of the brain: doctrine of multilevel analysis, „American Psychologist” 1992, Vol. 47, s. 1019-1028.

Heckman J.J., Investing in disadvantaged young children is an economically efficient policy, presented at the Committee for Economic Development/The Pew Charitable Trusts/PNC Financial 
Services Group Forum on „Building the Economic Case for Investments in Preschool”, New York, January 10, 2016, https://www.youtube.com/watch?v=pq ubRXwEXc\&feature=youtube [dostęp: 21.06.2019].

Lipman M., Filozofia w szkole, Centralny Ośrodek Doskonalenia Nauczycieli, Warszawa 2008. PBS Nova Documentary - Future Education - School of the future, 2016.

Projekt POKL „Umiem się uczyć” i „Potrafię. Wiem. Znam. Radę sobie dam”, Ewaluacja projektu: http://kiw-pokl.org.pl/media/upload/951/Raport\%20z\%20ewaluacji\%20zewn $\%$ C4\%99trznej. pdf [dostęp: 21.06.2019].

\section{Streszczenie}

Zjawiska społeczne wywierają wpływ na procesy rozwoju gospodarki i z tego punktu widzenia istotny jest problem marginalizacji i wykluczenia społecznego. Dodatkowo poczucie więzi z określonym terytorium i chęć pogłębiania wspólnego dobra przejawiają się w zaangażowaniu jego mieszkańców w realizację różnego typu projektów i programów. Zaangażowanie lokalnych wspólnot może stanowić podstawę uruchomienia procesów rozwojowych opartych na czynnikach endogennych.

Celem artykułu jest pokazanie, w jaki sposób wyniki badań z obszaru tzw. neuronauk mogą przyczynić się do lepszego radzenia sobie z problemami społecznymi regionów problemowych, przy których rozwiązywaniu wielokrotnie ponosi się porażki. Jako przykład posłużyć może aktywizacja osób wykluczonych lub zagrożonych wykluczeniem społecznym.

Słowa kluczowe: problemy społeczne, obszary problemowe, neuronauki

Numer klasyfikacji JEL: R19, O2, R1 